\title{
Biochemical Production of Adsorbents and Specialty Chemicals from Fossil Fuel Wastes
}

CRADA No. BNL-C-94-14

Summary Final Report

February 1998

E.T. Premuzic, BNL

M.S. Lin, BNL

T.H. Yen, UCLA

I. Yang, EER, Inc.

RECEIVIST

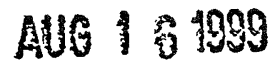

OSTI 


\section{DISCLAIMER}

This report was prepared as an account of work sponsored by an agency of the United States Government. Neither the United States Government nor any agency thereof, nor any of their employees, make any warranty, express or implied, or assumes any legal liability or responsibility for the accuracy, completeness, or usefulness of any information, apparatus, product, or process disciosed, or represents that its use would not infringe privately owned rights. Reference herein to any specific commercial product, process, or service by trade name, trademark, manufacturer, or otherwise does not necessarily constitute or imply its endorsement, recommendation, or favoring by the United States Government or any agency thereof. The views and opinions of authors expressed herein do not necessarily state or reflect those of the United States Government or any agency thereof. 


\section{DISCLAIMER}

Portions of this document may be illegible in electronic image products. Images are produced from the best available original document. 


\section{OBJECTIVE:}

To develop and/or modify biochemical processes for the conversion of fossil fuel wastes into valuable biomaterials. The experimental strategy based on the experiences gained in the program that dealt with the biochemical upgrading of heavy crude oils serves as a model in the development of the new technology.

\section{SIGNIFICANT ACCOMPLISHMENTS:}

1. Survey of Waste Oil Market and Current Recycle programs completed (EER, Inc.). The survey and the analysis included USA, France, United Kingdom, Germany, Sweden, Mexico, Brazil, Japan, Republic of China, Taiwan.

2. The existing hydrocarbon to protein technology $(\mathrm{H} \rightarrow \mathrm{P})$ has been modified and converted into an oil waste (UOPW) to biomass technology (UOPW $\rightarrow$ BM) (EER, Inc.)

3. The modified technology (2) produces fractionable biomass, protein, carbohydrates and lipids. The product yields have been optimized (BNL/EER).

4. Optimization R\&D effort has identified:

- Lower concentration of oil; larger concentration of biocatalyst phase. (BNL/EER)

- Cost-efficiency trade-offs based on the cost of produced water treatment relative to net cost gains based on product yields. (EER)

- $\quad$ Recycling and/or closed loop processes. (EER)

\section{SIGNIFICANT PROBLEMS:}

Some administrative, otherwise none. 


\section{INDUSTRY BENEFIT REALIZED:}

1. Variations in $\mathrm{H} \rightarrow \mathrm{P}$ technology to accomplish $\mathrm{UOPW} \rightarrow \mathrm{BM}$ defined and adapted which allowed to model the new technology (EER).

2. A pilot plant has been designed and economic analysis based on the pilot has shown that the modified technology is cost-efficient (BNL/EER).

3. The economic analysis has been projected to a large-scale operation, and modifications which are needed in the current technology have been defined (EER).

4. A Marketing Survey has been conducted and domestic and foreign customers identified (EER/).

\section{LABORATORY BENEFITS REALIZED:}

The BNL/EER, Inc. R\&D effort has contributed to BNL programs dealing with the oil cradle to grave cycle, particularly in terms of its chemistry, microbiology, engineering, environmental, and economic aspects. This is a significant and valuable contribution to the core fossil energy programs.

\section{RECOMMENDED FOLLOW-ON WORK:}

Continuing work will address specific optimization studies and elaborate on the engineering and economic design strategies. This is essential, because the completed studies, although very promising, are nevertheless, based on a model laboratory plant and projected assumptions.

\section{POTENTIAL BENEFIT FROM PURSUING FOLLOW-ON WORK:}

- Marketing of the live biomass as applied to the treatment of oils in sludge and bioremediation is economically attractive.

- Marketing of products derived from the biomass such as lipids and carbohydrates, because of the particular chemical properties of these products, is promising. Therefore, these products should be fully explored. Particular attention should be paid to the application of the treated biomass, the adsorbant and the lipids application in specialty products industries. 


\section{MAJOR PROGRESS:}

\section{Survey on Waste Oal Market and Carrent Recycle Programs}

In order to identify and contact customers interested in a joint venture domestically or from other countries, survcy on the wuste oil market for each specific region must be analyzed. Existing recycling tate and recycling options will be important factors to evaluate the feasibility of adaptation of this process in each specific region. Regulatory stnucture and enforcement ability on waste oil management differs with the country's size and political structure. Facilities in each country may be significantly different from one another. Particular attention and priority will be given to obtam funding for the construction of a larger pilot plant and field-testing of the performance of the bioproducts. The resource of the waste oil has to be identified first and has to be stable and reliable, and is readily available for the large pilot plant domestically or globally. Analysis on the representative waste oil samples is necessary in order to make adjustment in the unit operation of the process accordingly.

\section{USA}

In May of 1992, the United States Environmental Protection Administration issued standards establishing a presumption that all used oil is to be recycled unless a used oil handler disposes of used oil or sends used oil for disposal. Specific requirements and exemptions are listed in 40 CFR Part 279. Currently most states have adopted the faderal used oil management atandards, though some states have made some reversions. Five states inchuding California have adopted a more stringent approsch to used oil management by defining used cil as a hazardous waste.

Estimated about 1.5 billion gallons used oil is generated per year. Of that total,

$12 \%$ recycled into high quality products

$56 \%$ burned

$32 \%$ disposed illegally 


\section{France}

France imposes an very active used motor oil management program in order to conserve the nation's oil supply and to protect the envirnment by recycle and reuse the used oil. The waste oil collection program in France is currently adminstered by Agence de l'Environment et de la Maîtrise de l'Energie (ADEME).

In 1990, a repont by ADEME indicated that a total of 945,576 kilotons of oil is sold annually in France (most recent data available) and more than half of this oil is for automotive uses. The amount of used motor oil that has ben collected for recycling or reuse has increased from about 50 percent in 1990 to 78 percent in 1995. Used oil treatment facilities in France are either re-refining plants, combustion plants, reclaiming plants, or reprocessing plants. Direct burning, combustion accounts for more than 50 percent of used oil disposal. Re-refining of used oil then accounts for about 42 percent, while about 6 percent oil used oil is reclaimed. The most concem for the used oil management in France is the toxic contaminants like PCB, chinrine, and heavy metals in used oil.

\section{United Kingdom}

Total used oil production is 1 billion liters ( $\approx 264.20$ million gallons) per year. Of that total, about 500 millions liters ( $\$ 132.10$ million gallons) of the used oil are collected And among the collected used oil, about 240 millions liters ( $\approx 63.41$ million gallons) are recycled.

\section{Germany}

Germany regulates the collection, transportation, and disposal of waste oil. And it is remarkable that of the 690 kilotons of used motor oil produced annually, (Feb. 1996 dala) the government reported that 94 percent is collected and is either reprocessed (diesel, ship or gas oils) or burned (in cement kilns or as special waste). 


\section{Sweden}

There is no national used motor oil recycling program in Sweden, but used motor oil is classified and managed as hazandous waste. Since no national collection system is available to regulate the collection work, some gas stations offer environmental services such as used oil and used battery colloction About 70 percent of used motor oil in Sweden is collected and delivered to the cement industry to be used as fuel and incinerated effectively under controlled conditions.

\section{Mexico}

A proposal for updated used oil management program in Mexico is currently under active development and will be soon reviewed and approved by Secretariat of Social Development (Secretaria de Desarrollo Social - SEDESOL). Used motor oil has been regulated as hazardous waste in Mexico since 1988. The hierarchy for the treatment of used oils and lubricants established in the nale is in the following order. (1) re-refining, (2) combustion (3) incineration, and (4) confinement. In 1996, an estimated 300 million liters of used motor oil was generated in Mexico. But the information about the end uses af used oil remsined uncertain.

\section{Brazil}

Resolution Number 9, of August 31, 1993, is the national legislation on used motor oil recycling in Brazil. In the resalution, recycling is described as either recycling through regeneration or regucling though use. Discarding lubricant oils into the enviromment and the production/sale of unrecyclable new oil of both domestic and imported origin are prohibited. The law requires all used lubricant oil to be recycled. Recycle or reuse of used oil could be through re-refining, combustion for power generation, or incineration. The gas stations (marketers) collect used oil and sell to the reprocessing companies, who then recycle the oil and sell it back to the marketers. 
8. Japan

Waste oil recycling program in Japan is not at national level, nor major legislation is specifying the requitements for the managenent. However, though there are more than 40 million passenger cars and over 21 million trucks, buses, and other special purpose vehicles in Japan, almost no motor oil is changed by DIYers. Thus the collection and recycle percentage for used motor oil is very high.

\begin{tabular}{lll} 
& Collected & Recycled \\
\hline Lubricating oil [t] & $1,588,000$ & 900,000 \\
\hline Coobing oil [k] & 400,000 & 250,000 \\
\hline
\end{tabular}

The percentages for the option of the collected waste lubricating oil are as follow:

$60.1 \%$ bumed as fued

\section{$1.5 \%$ reprocessed for hibricating oil}

\section{$38.4 \%$ incinerated}

The end uses of the rocycled cooking oil are soap, paint, feed, fetilizer, and firel.

Due to lack of DIY motor oil changers in Japan, it is expected that there is very little public awareness or knowledge about used motor oil issucs. Also, the information about the contaminants in used oil is not reported publicly. The technologies for reclamation or recycle are comparatively low and can be improved, most reclaimers are small-scale business.

\section{Republic of China, Taiwan}

In 1995, the amount of waste hbricating oil recycled is about $1,260,300$ liters, which was estimated as $25.2 \%$ of total waste hubricating oil generated. No information is available about the end uses of collected used oil. Like the case in Japan, almost no motor oil changed by DrYers. 


\section{Review on Existing Recycling and Reuse Options}

Of that total 1.5 billion gallons waste oil generated each year in U.S., approximately only 12 percent is recycled into high quality products. The rest is either burned ( 56 percent) as low-grade fuel primary for space heaters, commercial and industrial boilers; or disposed illegally (32 percent) by landfilling incineration or dumping. Since the waste oil that is bumed is only minimally cleaned, as a result, harmful metals and other contaminants in the waste oil could be released into our enviroument. Furthermore, burning waste oil is not recycling waste oil to its highest and best value.

Waste oil is definitely a vital source of energy. Oil doesn't wear out; it just gets dirty after use. Waste oil can be re-refined into kubricating of, reprocessed as fuel oil, or used to as feedstock to produce petroleam-based products or other conmercially valuable products via different methods. There are some facts about conserving resources by proper handling of waste oil. Re-refining waste oil takes about $1 / 3$ of the energy needed to refine crude oil to lubricar quality, and one gallon of waste oil that is re-refined produces the same 2.5 quarts of labricating oil as 42 gallons of crude oil do. Therefore, collecting and recycling waste oil not only prorects our enviranment from waste oil contamisstion, it also conserve \& valuable non-renewable resource.

From the standpoint of energy conservation, recycling of waste oil efficiently saves a precious, nonrenewable tesource. Only one out of 70 barnds of corde oil is processed into virgin lube stock. That's why many oil companies spend billions of dollars on exploning recovering and refining crude oil into quality lube oil. If the waste oil generated by consumers can be recycled back to useful products such as pure hube oil again and again, tremendous time and money can be saved. More importantly, our natural resources can also be conserved.

\section{Reprocessing}

One of the economically attractive ways to manage waste oil is to bum it as fuel. Thus, most waste oils that are reprocessed are utilized as fuel. Processes such as adding 
chemicals, heating, filtration, and centrifugation or combinations of the above are able to separate the undesirable constituents from valuable portions. Odor produced from nitrogen and sulfur species is the greatest concem in operating these facilities. Severe corrosion may occur in the equipment when acidic gases from additive elements and water vapors combine during the process.

\section{Re-refining}

Waste oils can be re-refined into base lube oils. In general, water and dissolved low boiling point organic are removed by atmospheric or moderate vacuum distillation. Lube oil is then recovered and fractionated by distillation. Light ends byproducts are commonly used for plant combustion fuels. Diesel fraction and gas oil fraction can be recovered to high quality byproducts after further advanced treament Residual streams from distillation can be used by asphalt industry as asphalt fhux to produce roofing asphalt, paving asphalt, insulating materials, and other asphalt based products.

The major differences amoug all the processes are in how additives, impurities and sludge are removed. Considering technical feasibility, economical profitability, and operational easiness, re-refining processes are narrowed down to combinations of solvent treatment, distillation, hydrotreating, vacum distillation, clay polishing, chemical treatment, and demetallization. Marketability of products and byproducts will affect the combination choices of the processes. Processes, which do not generate hazardous wastes that are difficult to handic, will be preferred in the furture. Another problem is that the retail acceptance or recycled hube oil is not as great as expected.

\section{Combustion}

Waste oil can be thermally destroyed by incineration or combusted for energy utilization. Due to the economic benefit of recycling waste oils, only a very small quantity of waste oil is currently incinerated. And the oil that is incinerated generally has high concentration of toxic contaminants that makes recycling impratical or unsafe. One of the most common applications for recycled oils is used as fuels. Most 
reproceased oil combusted as fuels which at the same time replacing a virgin fuel oil is conomically favorable.

\section{Advantages of This Biochemical Process}

The change in virgin crude oil price can directly affect the waste oil recycling options. If the crude oil prices drop, petroleum product prices will fall accordingly. Gasoline and fuel oil prices track coude oil prices very closely, while lubricating ail prices react very slow with crude oil price change since lube oil contain many additives and other compunents that add to the final product cost A drop in crude oil price will decrease the value of reprocessed oil sold as a fuel supplement and as well as lower the ro-refiners' revenues. If higher-value products other than petroleum products can be recovered or produced from the waste oil by some new technologies, they could generate larger profit margins than reprocessed oil or re-refined oil as expected. Unfortunately, not many researches are towand to this direction. That's the uniqueness and superiority of this biochemical process to convert waste oil to commercially valuable products.

\section{Waste Oil Resources}

Automotive waste oils including engine crankcase oil, diesel engine oil, and hydraulic brake, transmission, power steering fluids constitute a large proportion of waste oils. Sources of automotive oil are do-it-yourself oil changers (DIYers), service stations, repair and maintenance shops, vehicle dealers, truck and taxi fleets, military installations, and industrial and manufacturing facilities. Another main category of waste oils is industrial waste oils, which include hubricating oil, hydraulic oil, grease, and process oil.

In most hubricating and industrial applications, the oil must he replaced by new oil when the performance of the oil deteriorates over time as additives break down and contaminants build up. But the fraction of the new oil that becomes waste oil varies widely for different applications. For example, only 10 percent of industrial process nils sold are generated as waste oil, compared to 90 percent of electrical transformer oils. The 
wasto oil generation rate for mutomotive oils is about 60 percent, which is a little bit higher than 52 percent for industrial oils. But the recycling rate for automotive oils (o 60 to 70 percent) is much higher than that for incustrial oils ( 825 to 40 percent).

Waste oils from different sources may have different constituents. Generally, waste oils often contain metals, chlorinated solveats, and other organic compounds, including those listed as priority pollutants by the U.S. EPA. Automotive waste oils tend to have high concentration of potentially hazardous heavy metak, usually as the result of engine or bearing wear, or the inclusion of these metals in oil additives. Industrial waste oils tend to have high level of chlorinated solvents and PCBs through careless management practices. The presence of organic compounds like benzene or naphthalene is usually associated with oil formulation itself The contaminants typically found in waste oils are listed in Table 1. These contaminants may be toxic to the bacteria strains used in the process to lower the product yields. So the selection of bacteris strains is very important for this process. If proper pretreatmem can be applied to the waste oil stock before sent to the fermenter to rernove these toxic contaminases, not only the efficiency of the process would be higher, but the product yields can also be raised.

Two gallons of the representative waste oil sample collected from Los Angeles area have been sent to BNL as feedstock for biomass production. Preliminary analysis conducted by instruments arch as ILC and ICP-MS on the waste cil sample was done. And the test for their suitability in the biomass production is under progress. The process yield and product performance will be evaluated later.

Table 1. Typical Contaminants in Waste Oils.

\begin{tabular}{|c|c|c|}
\hline Milexàn & Chiorinated Sotvents & Other Orzanic Compounds \\
\hline Cañnium & Dichlorodiffurorecthanc & Beazo(a)pyrenc \\
\hline Chrominm & Tichlorocthene & Benzo(a)anthracene \\
\hline Arsenic & Tetractloroethylene & $\mathrm{PCB}_{\mathrm{s}}$ \\
\hline Barium & 1,1,1-Trichloroetbane & Naphthalene \\
\hline Zinc & Trichlorotriffuaroethane & Benzenc \\
\hline \multirow[t]{2}{*}{ Lead } & Total chlorine & Tohrene \\
\hline & & Xylene \\
\hline
\end{tabular}


IV. Process Modification and Adjustment

1. The Hydrocarton to Protein $(\mathrm{H} \rightarrow$ P) Process

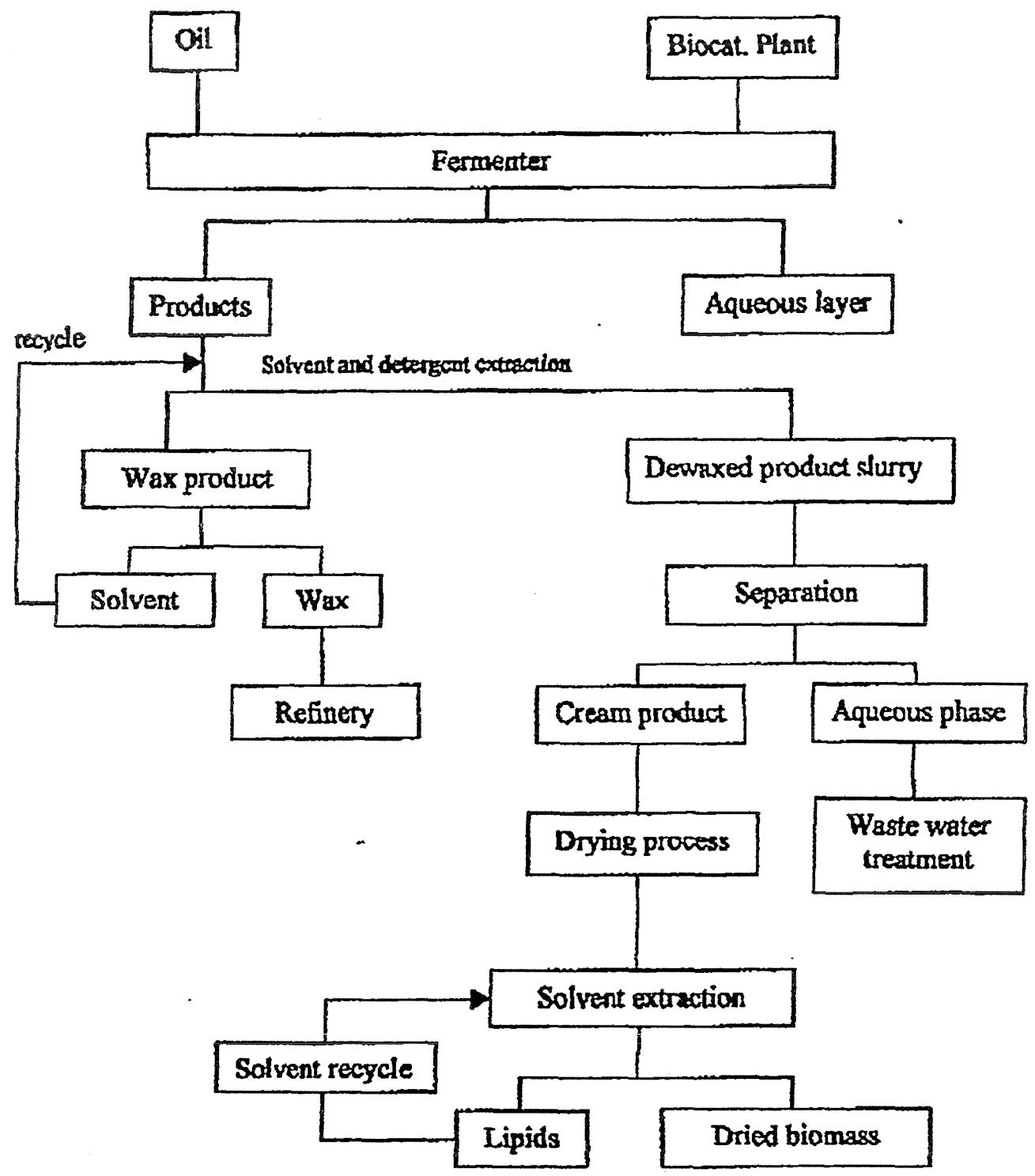

Detailed engincering design can be found in next three pages. 
Biomass Production from Oil Wastes - - Fermentation Section

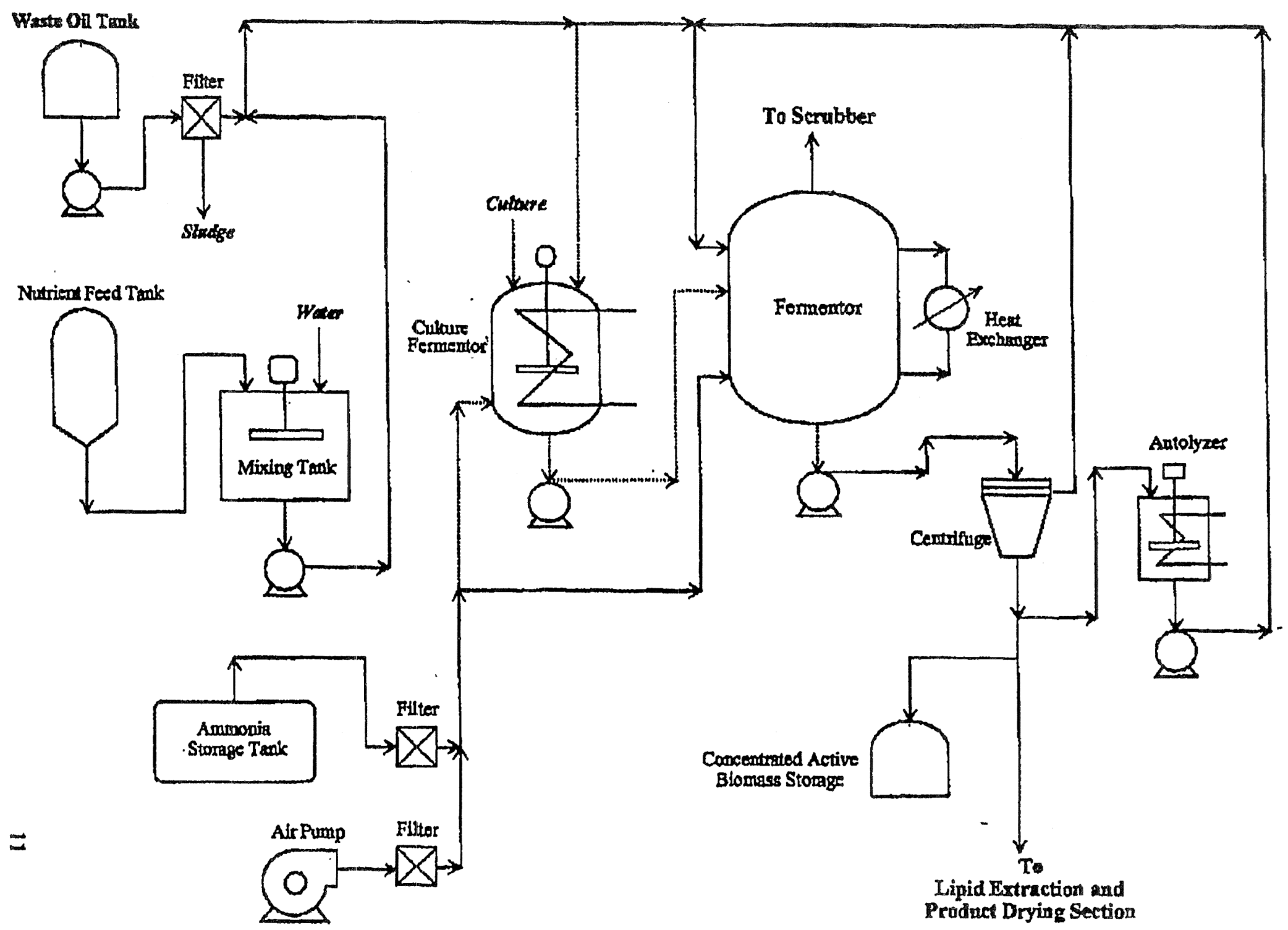


Biomass Production from Oil Wastes - Lipid Extraction and Product Drying Section

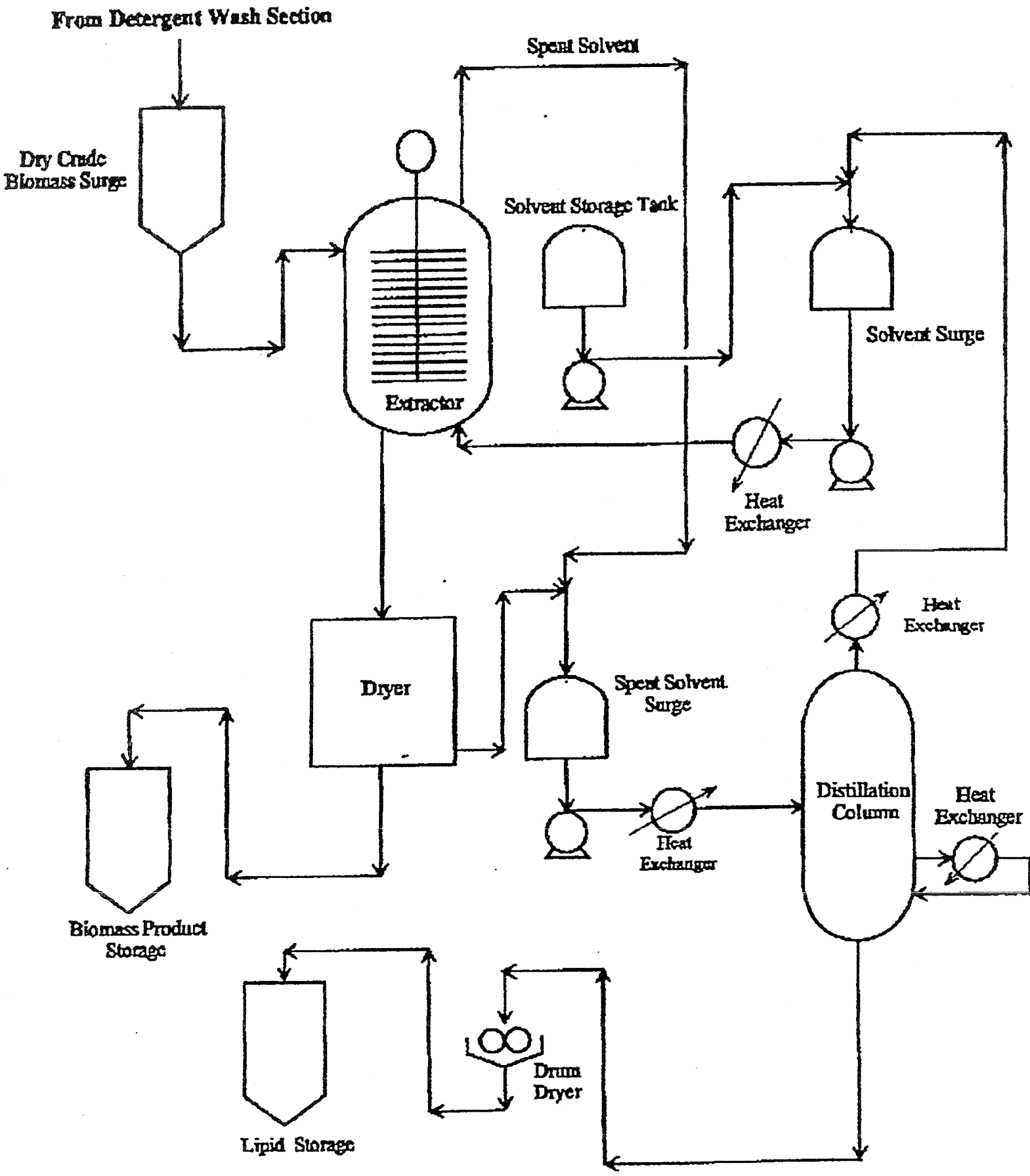




\section{Biomass Production from Oil Wastes m- Detergent Wash Section}

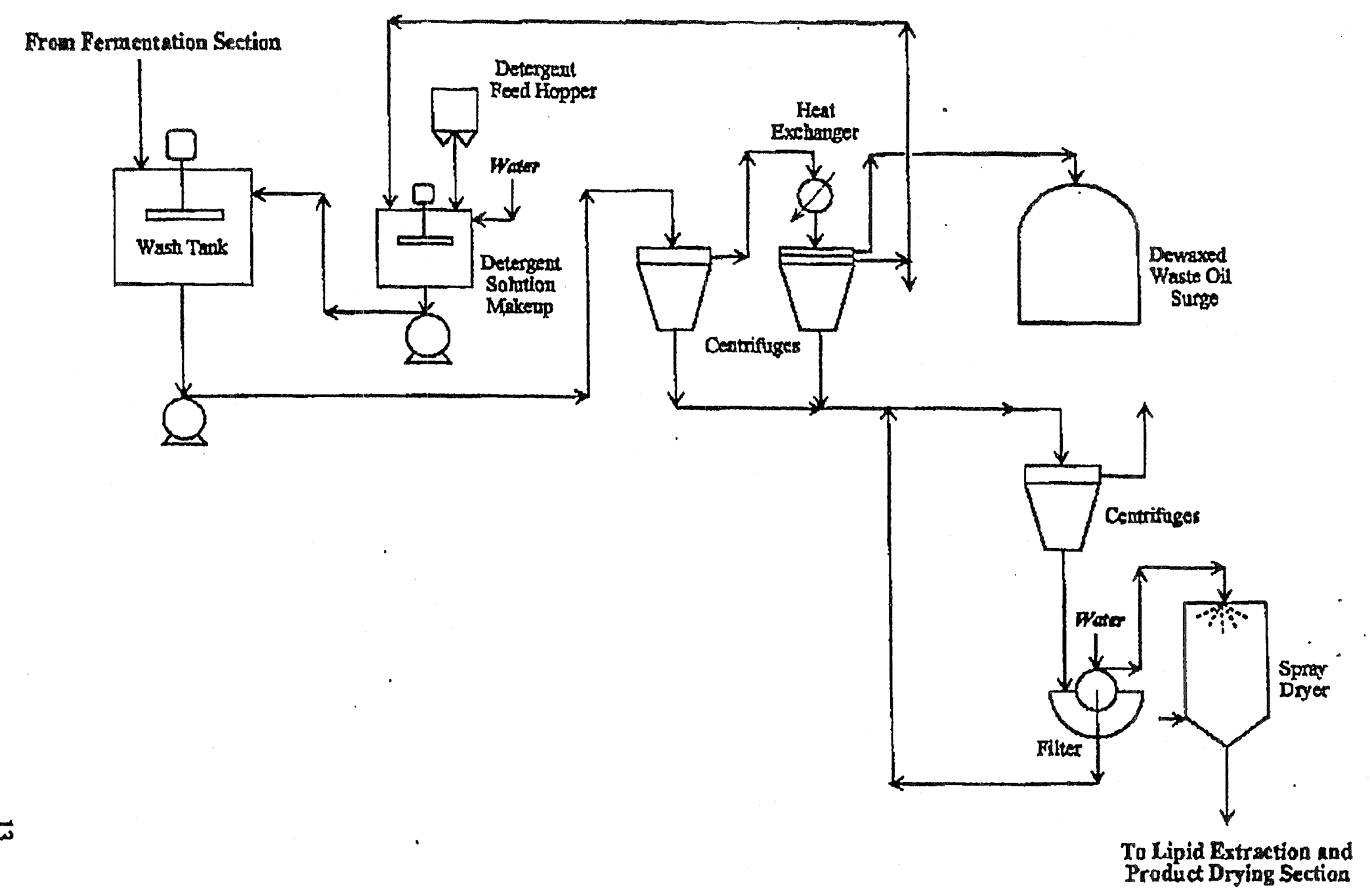


2. Current BNL Process:
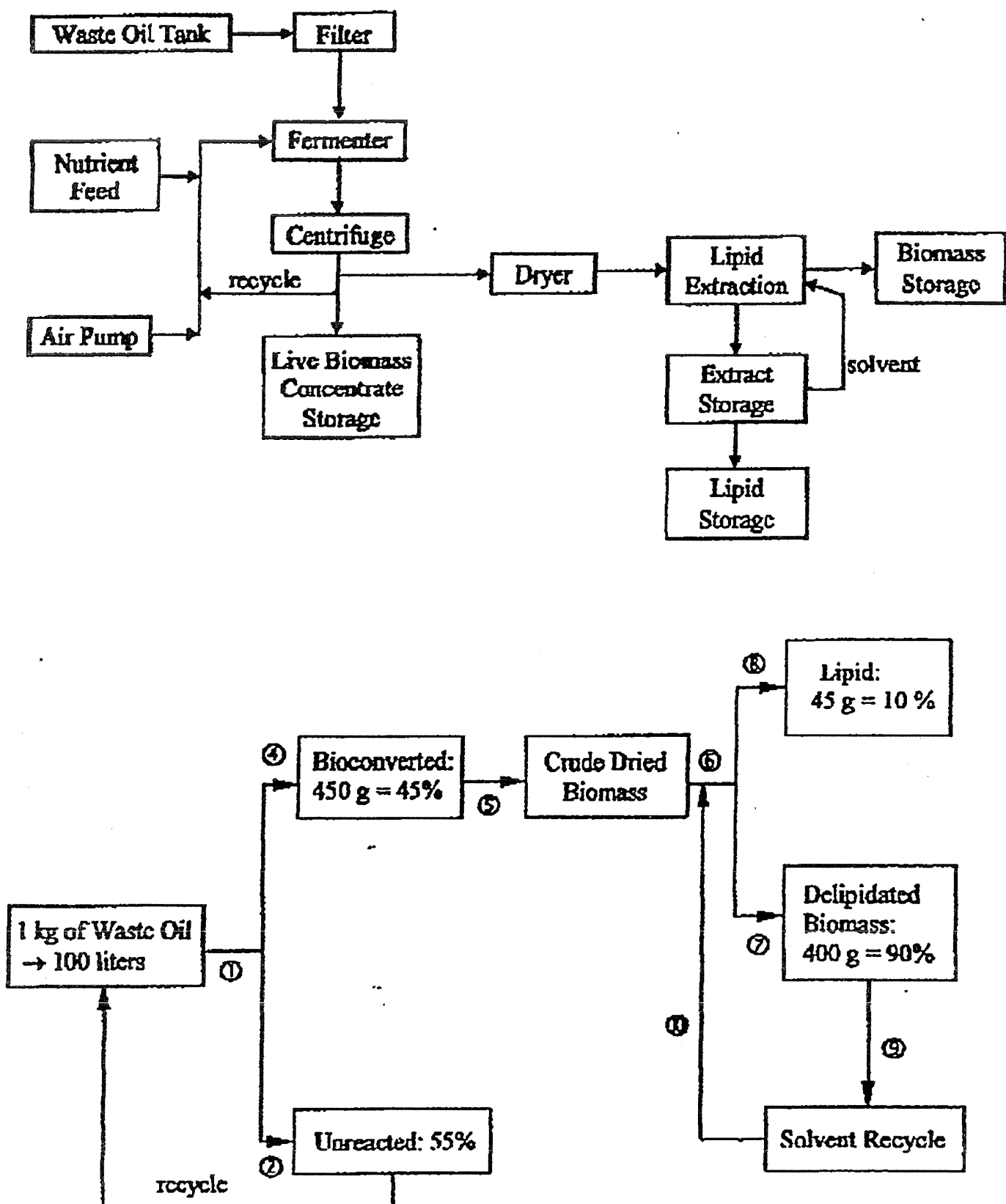

(1) 


\section{Specific analytical techniques of oil components}

The source of UOPW has to be identified and a background information of UOPW has to be established. To eliminate the adverse effects from heavy metals or PAHs in the waste oil to the microorganisms, it's better to remove both metals and PAHs prior to the fermentation process. Pretreatment options. may be varied with different source of UOPW. Some simple physico-chemical methods have been developed to convert any waste oil into a chemical form suitable for this biochemical process. In order to characterize different sources of UOPW for proper selection of pretreatment methods, a specific analytical procedure has to be used. The techniques inchude hydrocarbon type determination by GC-MS and metal determination by ICP-MS.

\section{Preliminary Economic Analysia}

Since the final engineering design is not very complete, detailed economic analysis can not be outlined at this time. However, through appropriate assumption and correlation to other similar $H \rightarrow P$ process, rough estimatinn can be obtained:

Total capital investment for a plant having capacity of 100,000 Metric tons/yr biomass production from waste oil can be, roughly estimated as follows:

\section{Assumptions:}

- 0.9 stream factor

- The annual biomass production is 100,000 tons.

- $10 \%$ of the production is lipid by-product and $90 \%$ is delipidated biomass.

- The production cost exchudes any credit for lipid by-product and licensing expenses.

- The cost for waste oil consumed is 8.08 cent $/ \mathrm{kg}$

- The process yield is $50 \mathrm{~kg}$ product per $100 \mathrm{~kg}$ waste oil consumed.

where CE Cost Index $=389.7$ (for Ott. 1997) 
So,

Total capital investment, not inchding land: $\$ 160$ million

Total fixed capital investment:

$\$ 126$ million

Total production cost per year:

$\$ 78.3$ million

$\approx 78.3 \mathrm{cont} / \mathrm{kg}$

\section{VL. Marketing of the Biaproduct and Cooperation of the Technology}

Marketing of the live biomass applied to treatment of oils in sludge and bioremediation of zoils contaminated with waste oil is initiated. Since current data are encouraging and very promising for live biomass to be used in these two applications. selection of suitable sites for freld testing is in progress in order to gather real field data. This can attract mone customers to get inwohed for a joint yenture. Marketing of lipids and delipidated biomass is also in progress by contacting with many potential partmers for various applications.

Many domestic and forcign customers have been contacted in order to seck the chance for a joint venture. Domestic customers are mostly enviromental consalting or environmental service companies. They did show highly interest in helping to get in touch with many clients that need to clean up oil-contaminated sites to try this technology for field testing. Foreign contacts concentrate on gating cooperative partmership and then the key issue is trying to obtain funding for the construction of a larger pilot plant. According to the research on waste oil market, it makes more sense and also easier to find interest parties from European countries or Japan. Since single cell protain process has been practicing in Europe for a long time, and most European countries and Japan have better wasto oil recycle program to ensure steady waste oil feedstock for this procesf Furthermore, the benefit from this process that the biomass (protein) produced to be used as animal feed would attract European countries and Japan that are highly
dependent on corn or soybean import. The list of companies and contact persons are as
follow: 
1. Dr. Mike H. Shoeleh

Water-Floc Environtmental Service, inc.

4000 MacArthur Blvd., Suite 3000

Newport Beach, CA 92660

(714) $851-6501$

2. Dr. Alon Lebel

Invirotrear Inc.

201 Center St.

Anaheim, CA 92805

(714) $517-8658$

3. Dr. Ming Wang

OCET Corp.

11588 Sorrento Valley Rd., Suite 21

San Diego, CA 92121

(619) $259-4375$

4. Dr, Shaik A. Qader

- Energy and Envirommental Technology

11609 Treviso Way,

Rascho Cucamongs, CA 91701-8697

(909) 466-6266

5. Mr. Gusro Quarter

Fossil Energy

23342 S. Pointe

Laguna Hill, CA 92653

(714) $859-4466$

6. Mr. Jim Tart

Stone Lions Environmental Corp.

1148 Manhattan Ave, \#1

Manhattañ Beach, CA 90266

(310) 546-2553.

7. Mr. Ryuzo Takana

Organic Chemistry Section

Central Research Laboratories

Idemitsu Kosan Co., Ltd.

1280 Kamiizumi, Sodegaura

Chiba 299-02 Japan

81-438-75-22.67 
8. Ms. Ting-Wei Kwo

The Center for Energy and Environmental Studies

Chung-Helsa Institution for Economic Research

75 Chang-Hsin St.

Taipei, Taiwan, R.O.C.

886-2-2735-6006

9. Ms. Alice Chen

China Technical Consultants, Inc.

16F1, 695 Tunkwa S. Road

Taipci, Taiwan, R.O.C.

886-2-2709-9309

10. Dr. Frank Shiu and Dr. Jerry Lin

Energy and Rescurces Laboratories

Industrial Technology Research Institute

Bkig. 24, 195-196, Sec.4

Chung Hsing Rd.

Clutung, Hsinchu, Taiwan, R.O.C.

886-3-591-5485

\section{References:}

Nemerow, Nelson L., and Avijit Dasgupta, Indkstrial and Hazardous Waste Treatment. Van Nostrat Reinhold, New York, 1991, p 658-661, 691-692.

Tchobanoglous, George, Hilary Theisen, and Samucl A. Vigil, Integrated Sotd Waste Mossagement. MoGraw Hill, New York, 1993, p 754-758.

American Petrolerm lestitute, National Used Ot Collection Study, Washington, D.C, May 1996.

Enorgy and Envinonmental Research Corporation, Guide to Cil Waste Management Alternatives. Irvine, CA., April 19898.

Proceedings of the International Conference on Waste Oil Recovery and Reuse, February 12-14, 1974, Washington, D. C., sponsored by Association of Petroleum Re-Refiners, presented by Informstion Transfer. The Re-Refiners, Arlington, VA, c1974. 
American Petroleum Institute, Sirty of Usud Matar Oil Recycling in Eleven Selected Countries, Washington, D.C., November 1997.

Mueller Associates, Inc., Waste Oil: Reclainting Technology, Utilization, and Dispassal. Park Ridge, N.J., Noyes Data Corp. 1989.

Irwin, William A and Richard A. Liroff, Used Oil Low in the United Stutes, prepared for Office of Research and Development, U.S. Environmensal Protection Agency. U.S. Govt. Print. Off, 1974.

Office of Reseanch and Development, United States Environmental Protection Agency, Emviromental Regulations and Technology: Mamaging I/sed Motor Oil. HPA625/R94/010, Washington, D.C., Dec. 1994.

Hess, L. Y., Reprocessing and Disposal of Waste Petroleam Oils. Park Ridige, N.J.: Noyes Data Corporation, 1979.

Califomiz Integrated Waste Management Board, Used Oil Collection Demonstration Grant Program: Final report. Sacramento. 1994. 